\title{
The consumer behavior in different retail formats in Brazil
}

\section{Sergio Silva Braga Junior ${ }^{1, ~ *}$, Evandro Luiz Lopes $^{2}$, Eduardo Guilherme Satolo ${ }^{1}$, Dirceu da Silva ${ }^{2}$, Sergio Luiz do Amaral Moretti ${ }^{3}$}

${ }^{1}$ UNESP - Univ. Estadual Paulista, Tupã Campus,São Paulo, Brazil

${ }^{2}$ University Nine de July, São Paulo, Brazil

${ }^{3}$ Superior School of Advertising and Marketing, São Paulo, Brazil

\section{Email address:}

sergio@tupa.unesp.br (S. S. Braga Junior), elldijo@uol.com.br (E. L. Lopes), eduardo@tupa.unesp.br (E. G. Satolo), dirceuds@gmail.com (D.da Silva),sergiomoretti@uol.com.br (S. L. do A. Moretti)

\section{To cite this article:}

Sergio Silva Braga Junior, Evandro Luiz Lopes, Eduardo Guilherme Satolo, Dirceu da Silva, Sergio Luiz do Amaral Moretti. The Consumer Behavior in different Retail Formats in Brazil. Science Journal of Business and Management. Vol. 2, No. 1, 2014, pp. $24-34$. doi: $10.11648 /$ j.sjbm.20140201.14

\begin{abstract}
Research demonstrates the applicability of the RSQ scale within the Brazilian context in different retail formats and compares the consumers' perceptions for each format. Three surveys comprising 690 consumers from retail shop were performed in different formats (banking service, sports shop and clothes shop) in São Paulo SP Brazil, due to its first ranking within the Brazilian market. Data collection was performed through direct contact with clients. Modeling of structural equations with estimation matrix by partial minimum squares showed that RSQ scale identified the five theoretical factors of perceived quality and made possible the verification of greater and less relevant points in each retail format. High coefficients of determination were underscored in data analyses to determine the factors Personal Interactions and Trust. The Brazilian market is being underscored within the international scenario due to its increasing consumption and rapid recovery after several world economical crises. The analysis of perceived quality of services by Brazilian firms is highly relevant for the understanding of consumers' profile and for tying strategies of services with consumers' expectations. Although gaps exist in service quality measuring scales, current analysis used the scale invented by Dabholkar, Thorpe and Rentz (1996) denominated RSQ - Retail Service Quality. The scale presents the required amplitude to measure constructs in all retail sectors, as shown in current investigation. By employing the scale's criteria, the relevance and originality of current study lies in the identification and comparison of the different qualities perceived by consumers for each retail format analyzed.
\end{abstract}

Keywords: Consumer Behavior, Retail Service Quality, Perceived Quality, Retail in Brazil

\section{Introduction}

Although Perceived Quality is a classical theme in studies on consumer behavior, it still provokes great interest in many Brazilian and foreign scholars. A research on Scholar Google revealed more than 400 academic research works on the theme in Brazil during the last three years. EBSCO data base also demonstrated 984 papers published on the same theme during the same period.

The amount of scientific investigations in this field is common enough since many academics think that Perceived Quality is one of consumers' main loyalty antecedents (Parasuraman, Zeithaml, and Berry, 1985; Cronin and Taylor, 1992; Dabholkar, Thorpe, and Rentz, 1996; Hong and Goo, 2004). Due to research consistency on the subject, most theoretical and practical studies deal with the identification, development and application of psychometric scales that safely and parsimoniously measure consumers' perceived quality. Some are for broad application - SERVQUAL (Parasuraman, Zeithaml, and Berry, 1988) and SERVPERF (Cronin and Taylor, 1992), while others have been conceived for specific contexts, such as SPS - Sales Performance Scale (Sujan, Weitz, and Kimar, 1994) for sales; PDSQ - Physical Distribution Service Quality (Beinstock, Mentzer, and Bird, 1997) for logistic services; EXCEL - Excellence in Business (Sharma, Netemeyer and Mahajan, 1990) for measuring service excellence; and RSQ - Retail Service Quality (Dabholkar, Thorpe and Rentz, 1996) which measures perceived quality in the retail segment service.

Current analysis is a comparative analysis of service Perceived Quality in three distinct retail formats and identifies the relationship between perceived quality and its 
theoretical aspects in the retailers under investigation. The essay also proposes to demonstrate the applicability of the RSQ scale within the Brazilian context. If several applications of the RSQ scale have been employed within the international scenario in the last fifteen years, it is still hardly known in Brazil. Current essay comprises five sections introduced by this brief introduction. Section 2 contains a theoretical review of the RSQ scale, whilst the third section comments on the methodological aspects of the study's empirical stage. The fourth section discusses results and the final section is dedicated to end comments.

\section{Literature Review}

\subsection{RSQ - Retail Service Quality Model}

In 1996, Pratibha Dabholkar, Dayle Thorpe and Joseph Rentz became aware that gaps existed in service quality measuring scales since in their view no scale with the required amplitude was extant to undertake measurement of the construct in all business sections.

According to these authors, the competitive environment of retail is in constant flux due to continuous increasing growth in the intensification of competition among home and foreign enterprises and in the number of incorporations and acquisitions. Another factor was the increase of consumers' demands. Current retailers, therefore, were obliged to implement differentiation strategies and base their activities on their clients' necessities and expectations.

Although researchers agree that SERVQUAL scale is the most 'intensely and applied' tool to measure service quality, they state that the scale was empirically tested in a great number of experiments that involve enterprises providing 'pure' services. The scale is highly trustworthy when applied to enterprises in which the commercialization of physical products is not extant at least on a large scale. They also remark that the tool had not been successfully adapted to the retail shop milieu with different characteristics from those in pure service enterprises. In fact, clients of retail firms go about the shop at will and frequently find the required product autonomously. They interact with several members of the firm's staff, return and exchange products. Others develop activities that affect the evaluation of service quality from the clients' point of view (Dabholkar, Thorpe, \& Rentz, 1996).

Foregrounded on the differences among retail shops and other service providers, Dabholkar, Thorpe and Rentz (1996) believe that other aspects within the retail milieu besides those indicated by the SERVQUAL scale by Parasuraman, Zeithaml and Berry $(1985,1988)$, are required.

Several applications in which SERVQUAL is employed do not identify the quality aspects proposed by their inventors, as Table 1 demonstrates.

Dabholkar, Thorpe and Rentz (1996) highlighted studies by Guiry, Hutchinson and Weitz (1992), who adapted the 22 questions of the SERVQUAL scale by eliminating 7 and including 36. Data analysis showed seven aspects to measure quality in retailing: (1) attendance; (2) variety of products; (3) reliability in commercial transactions; (4) availability of staff for client attendance; (5) tangible aspects; (6) reliability in the shop's service policy; (7) price. Although the study is a good start to construct a retail quality measurement scale, it was soon abandoned because price inclusion as a quality factor was not accepted by researchers. Price is an important determinant in the choice of a shop but no studies exist to prove its relationship with the perceived quality of services provided.

Table 1. Applications of the SERVQUAL scale in retail.

\begin{tabular}{|c|c|c|c|}
\hline Researcher & Application & Methodology & Perceived results \\
\hline $\begin{array}{l}\text { Carman } \\
(1990)\end{array}$ & $\begin{array}{l}\text { Tires, } \\
\text { dentistry } \\
\text { school, } \\
\text { intensive } \\
\text { care } \\
\text { hospital. }\end{array}$ & $\begin{array}{l}\text { Modified } \\
\text { SERVQUAL } \\
\text { scale was } \\
\text { employed, with } \\
12 \text { and } 22 \\
\text { questions. }\end{array}$ & $\begin{array}{l}\text { Result was significant } \\
\text { in all applications, } \\
\text { excepting the tire shop } \\
\text { - it was the only one in } \\
\text { which product } \\
\text { commercialization was } \\
\text { great. }\end{array}$ \\
\hline $\begin{array}{l}\text { Finn \& } \\
\text { Lamb } \\
(1991)\end{array}$ & $\begin{array}{l}\text { Four } \\
\text { different } \\
\text { types of } \\
\text { retail shops. }\end{array}$ & $\begin{array}{l}\text { Original } \\
\text { SERVQUAL }\end{array}$ & $\begin{array}{l}\text { Validation of scale was } \\
\text { not possible in any of } \\
\text { the cases under } \\
\text { analysis. }\end{array}$ \\
\hline $\begin{array}{l}\text { Guiry, } \\
\text { Hutchinson } \\
\text { \& Weitz } \\
\text { (1992) }\end{array}$ & Retail shop & $\begin{array}{l}\text { Modifies } \\
\text { SERVQUAL, } \\
\text { with } 51 \text { question } \\
\text { pairs, of which } 15 \\
\text { were original and } \\
36 \text { were new }\end{array}$ & $\begin{array}{l}\text { Validated a model with } \\
7 \text { aspects and not } \\
\text { merely the original } 5 \text {. }\end{array}$ \\
\hline
\end{tabular}

Source: Dabholkar, Thorpe and Rentz (1996).

Consequently, Dabholkar, Thorpe and Rentz (1996) thought that a scale that would measure perceived quality in retail service was necessary and they started a triangulation of empirical research work. By means of interviews with clients at shop exits, the researchers tried to identify quality attributes related to the buying experience in retail shops which would be relevant to the clients. The study showed that clients were highly interested in the physical layout of the shop since they had to move around and find the required objects on their own. Great interest was shown in the care the personnel meted out, in the comfort that the shop provided, in the policy of accepting credit cards and the ease in returning or changing bought products.

The second research comprised six in-depth interviews with clients of retail shops. They tried to discover other relevant attributes which had not been mentioned in the first series of interviews. Several attributes identified in the first series were corroborated by the second, among which may be mentioned disposal of aisles, care by personnel and ease in returning products. Other attributes were also identified, such as the pleasant layout of the shop and facilities available, such as toilets, fitting rooms, parking space and others. Interviewed clients also commented on the importance that commitments in purchases were honored.

The third stage of qualitative triangulation employed the 'follow' technique of clients within the shop and observed their behavior. Interviews were recorded while clients were 
strolling along the aisles, when they interacted with staff and displayed products. When they decided to buy a specific object, they reported what they were thinking and why they opted for such a product and not another. The authors registered that the buying experience and clients' interactivities with other factors in the milieu were collected without any significant alterations of the natural flux. Participants commented on the layout of the shop, the aisles, availability of personnel and its quality, and on the quality of the products displayed.

When Dabholkar, Thorpe and Rentz (1996) combined results provided during the exploratory stage with the theoretical presuppositions developed, they prepared a hierarchical structure of factors that determined quality service for retail shops. Similar to Parasuraman, Zeithaml and Berry (1985, 1988), researchers Dabholkar, Thorpe and Rentz (1996) suggested that perceived quality was determined by five distinct factors, or rather, physical aspects with two sub-factors (layout and comfort); reliability with two sub-factors (commitment and positivity); personal interactions (subdivided into care/courtesy and reliability; problem solution; internal policies of the retail shop. According to Dabholkar, Thorpe and Rentz (1996), the above theoretical factors determined the identification of consumers' perceived quality. Table 2 demonstrates the operational definition of each proposed factor.

Table 2. Aspects of quality according to the RSQ model.

\begin{tabular}{|c|c|c|}
\hline Factor & Sub-factor & Operational definition \\
\hline \multirow{2}{*}{$\begin{array}{l}\text { Physical } \\
\text { aspects }\end{array}$} & Layout & $\begin{array}{l}\text { Cleanliness, general layout of the shop } \\
\text { and support sites, layout of departments } \\
\text { and aisles. }\end{array}$ \\
\hline & Comfort & $\begin{array}{l}\text { Ease in finding the required product; ease } \\
\text { to move around the aisles; } \\
\text { air-conditioning of the shop. }\end{array}$ \\
\hline \multirow[t]{2}{*}{ Reliability } & Commitment & $\begin{array}{l}\text { Commitments and business schedules } \\
\text { honored; maintenance of good quality } \\
\text { products. }\end{array}$ \\
\hline & Positivity & $\begin{array}{l}\text { Effort to do the correct thing in the first } \\
\text { instance. }\end{array}$ \\
\hline \multirow{2}{*}{$\begin{array}{l}\text { Personal } \\
\text { Interactivities }\end{array}$} & $\begin{array}{l}\text { Transmitting } \\
\text { reliability }\end{array}$ & $\begin{array}{l}\text { Staff should transmit reliability to clients } \\
\text { and clients should trust the information } \\
\text { given by the personnel. }\end{array}$ \\
\hline & $\begin{array}{l}\text { Care and } \\
\text { courtesy }\end{array}$ & $\begin{array}{l}\text { Personnel should display good will and } \\
\text { courtesy when clients need care or when } \\
\text { they have doubts. }\end{array}$ \\
\hline $\begin{array}{l}\text { Problem } \\
\text { solution }\end{array}$ & & $\begin{array}{l}\text { Procedures adopted by retailers with } \\
\text { regard to returns and change of products; } \\
\text { the manner complaints are registered and } \\
\text { dealt with. }\end{array}$ \\
\hline $\begin{array}{l}\text { Internal } \\
\text { policy }\end{array}$ & & $\begin{array}{l}\text { Policy of accepting credit cards and } \\
\text { installments through specific cards, } \\
\text { attendance timetable, availability of } \\
\text { parking spaces. }\end{array}$ \\
\hline
\end{tabular}

Source: based on Dabholkar, Thorpe \& Rentz (1996).

\subsection{Development of RSQ Scale}

Scale proposed by Dabholkar, Thorpe and Rentz (1996) comprises 28 questions, 17 adapted from the SERVQUAL scale and 11 developed by the quality triangulization undertaken. Although the factors in the RSQ and SERVQUAL were different, the authors reported being at ease to employ 17 out of the 22 original questions of the SERVQUAL scale since they were foregrounded on "extensive quality research" developed by Parasuraman, Zeithaml and Berry (1985).

Table 3 compares RSQ scale and its factors with those of the SERVQUAL scale.Items were evaluated by a Likert-type scale with 5 points, featuring (1) total disagreement and (5) total agreement.

Table 3. $R S Q$ scale.

\begin{tabular}{|c|c|c|c|}
\hline \multirow{2}{*}{$\begin{array}{l}\text { Servqual } \\
\text { Factor }\end{array}$} & \multicolumn{2}{|c|}{ RSQ } & Statement \\
\hline & Factor & $\begin{array}{l}\text { Sub- } \\
\text { factor }\end{array}$ & \\
\hline Tangible & $\begin{array}{l}\text { Physical } \\
\text { aspect }\end{array}$ & Display & $\begin{array}{l}\text { P1- Shop has modern apparatuses } \\
\text { and furniture }\end{array}$ \\
\hline Tangible & $\begin{array}{l}\text { Physical } \\
\text { aspect }\end{array}$ & Display & P2- Support annexes are nice \\
\hline Tangible & $\begin{array}{l}\text { Physical } \\
\text { aspect }\end{array}$ & Display & $\begin{array}{l}\text { P3- Materials related to service } \\
\text { (bags, catalogues, leaflets) } \\
\text { satisfying. }\end{array}$ \\
\hline (NES) & $\begin{array}{l}\text { Physical } \\
\text { aspect }\end{array}$ & Display & $\begin{array}{l}\text { P4- Cleanliness of shop, including } \\
\text { toilets and rest rooms, are adequate. }\end{array}$ \\
\hline (NES) & $\begin{array}{l}\text { Physical } \\
\text { aspect }\end{array}$ & Comfort & $\begin{array}{l}\text { P5- Shop layout makes it easy for } \\
\text { the client to find the required } \\
\text { product }\end{array}$ \\
\hline (NES) & $\begin{array}{l}\text { Physical } \\
\text { aspect }\end{array}$ & Comfort & $\begin{array}{l}\text { P6- Shop layout makes it easy for } \\
\text { the client to move around }\end{array}$ \\
\hline Reliability & Reliability & $\begin{array}{l}\text { Commit } \\
\text { ment }\end{array}$ & $\begin{array}{l}\text { P7- When the shop commits itself, } \\
\text { it delivers the product within } \\
\text { schedule. }\end{array}$ \\
\hline Reliability & Reliability & $\begin{array}{l}\text { Commit } \\
\text { ment }\end{array}$ & P8- Shop keeps its promises. \\
\hline Reliability & Reliability & $\begin{array}{l}\text { Positivit } \\
\mathrm{y}\end{array}$ & $\begin{array}{l}\text { P9- Shop correctly manages its } \\
\text { services at once }\end{array}$ \\
\hline (NES) & Reliability & $\begin{array}{l}\text { Positivit } \\
\mathrm{y}\end{array}$ & $\begin{array}{l}\text { P10- Shop makes available } \\
\text { products which clients require }\end{array}$ \\
\hline Reliability & Reliability & $\begin{array}{l}\text { Positivit } \\
\mathrm{y}\end{array}$ & $\begin{array}{l}\text { P11- Shop makes great efforts to } \\
\text { registers business tractions and data } \\
\text { without flaws }\end{array}$ \\
\hline Safety & $\begin{array}{l}\text { Personal } \\
\text { interaction }\end{array}$ & $\begin{array}{l}\text { Inspiring } \\
\text { reliabilit } \\
\mathrm{y}\end{array}$ & $\begin{array}{l}\text { P12- Personnel are capable of } \\
\text { solving the clients' doubts }\end{array}$ \\
\hline Safety & $\begin{array}{l}\text { Personal } \\
\text { interaction }\end{array}$ & $\begin{array}{l}\text { Inspiring } \\
\text { reliabilit } \\
\mathrm{y}\end{array}$ & $\begin{array}{l}\text { P13- Personnel's behavior inspires } \\
\text { reliability in clients }\end{array}$ \\
\hline Safety & $\begin{array}{l}\text { Personal } \\
\text { interaction }\end{array}$ & $\begin{array}{l}\text { Inspiring } \\
\text { reliabilit } \\
\mathrm{y}\end{array}$ & $\begin{array}{l}\text { P14- Client feels assured in } \\
\text { undertaking commercial } \\
\text { transactions with the shop }\end{array}$ \\
\hline $\begin{array}{l}\text { Promptnes } \\
\mathrm{s}\end{array}$ & $\begin{array}{l}\text { Personal } \\
\text { interaction }\end{array}$ & $\begin{array}{l}\text { Care / } \\
\text { Courtesy }\end{array}$ & $\begin{array}{l}\text { P15- Personnel are always available } \\
\text { to attend to clients }\end{array}$ \\
\hline Pronptness & $\begin{array}{l}\text { Personal } \\
\text { interaction }\end{array}$ & $\begin{array}{l}\text { Care / } \\
\text { Courtesy }\end{array}$ & $\begin{array}{l}\text { P16- Personnel give precise } \\
\text { information on schedule in which } \\
\text { services are undertaken }\end{array}$ \\
\hline $\begin{array}{l}\text { Promptnes } \\
\mathrm{s}\end{array}$ & $\begin{array}{l}\text { Personal } \\
\text { interaction }\end{array}$ & $\begin{array}{l}\text { Care / } \\
\text { Courtesy }\end{array}$ & $\begin{array}{l}\text { P17- Personnel are always available } \\
\text { to solve clients' doubts }\end{array}$ \\
\hline Empathy & $\begin{array}{l}\text { Personal } \\
\text { interaction }\end{array}$ & $\begin{array}{l}\text { Care / } \\
\text { Courtesy }\end{array}$ & $\begin{array}{l}\text { P18- Shop provides personal } \\
\text { attention to clients }\end{array}$ \\
\hline Safety & $\begin{array}{l}\text { Personal } \\
\text { interaction }\end{array}$ & $\begin{array}{l}\text { Care / } \\
\text { Courtesy }\end{array}$ & P19- Personnel are always affable \\
\hline$(N E S)$ & $\begin{array}{l}\text { Personal } \\
\text { interaction }\end{array}$ & $\begin{array}{l}\text { Care / } \\
\text { Courtesy }\end{array}$ & $\begin{array}{l}\text { P20- Personnel are always affable } \\
\text { on the phone }\end{array}$ \\
\hline (NES) & $\begin{array}{l}\text { Problem } \\
\text { solution }\end{array}$ & - & $\begin{array}{l}\text { P21- Shop makes easy return and } \\
\text { change of products }\end{array}$ \\
\hline Reliability & Problem & - & P22- When the client has \\
\hline
\end{tabular}




\begin{tabular}{|c|c|c|}
\hline Servqual & RSQ & Statement \\
\hline & solution & $\begin{array}{l}\text { complaints, the shop shows great } \\
\text { interest in sincerely finding a } \\
\text { solution. }\end{array}$ \\
\hline (NES) & $\begin{array}{l}\text { Problem } \\
\text { solution }\end{array}$ & $\begin{array}{l}\text { P23- Personnel are competent to } \\
\text { personally solve doubts and } \\
\text { complaints }\end{array}$ \\
\hline (NES) & $\begin{array}{l}\text { Internal } \\
\text { policy }\end{array}$ & $\begin{array}{l}\text { P24- Shop provides high quality } \\
\text { products }\end{array}$ \\
\hline (NES) & $\begin{array}{l}\text { Internal } \\
\text { policy }\end{array}$ & $\begin{array}{l}\text { P25- Shop provides extensive } \\
\text { parking space }\end{array}$ \\
\hline Empathy & $\begin{array}{l}\text { Internal } \\
\text { policy }\end{array}$ & $\begin{array}{l}\text { P26- Shop schedule hours are } \\
\text { convenient to clients }\end{array}$ \\
\hline (NES) & $\begin{array}{l}\text { Internal } \\
\text { policy }\end{array}$ & $\begin{array}{l}\text { P27- Shop receives all type of credit } \\
\text { cards }\end{array}$ \\
\hline (NES) & $\begin{array}{l}\text { Internal } \\
\text { policy }\end{array}$ & $\begin{array}{l}\text { P28- Shop provides its own credit } \\
\text { card }\end{array}$ \\
\hline
\end{tabular}

Note: (NES) Non extant SERVQUAL scale

Source: Dabholkar, Thorpe \& Rentz (1996)

\subsection{Validation of RSQ Scale}

Dabholkar, Thorpe and Rentz (1996) applied empirically the RSQ scale in seven retail shops for validation. The shops, belonging to two different networks in the southwestern region of the USA, traded in similar products to similar-profile clients. Samples comprised 227 answers from 197 females, average age 43 years, and 27 males, average age 40 years. Questionnaires were filled by the clients immediately after a visit to the shop. Above methodology was employed, following Rust \& Oliver (1994 apud Dabholkar, Thorpe, \& Rentz, 1996) who were of the opinion that immediate interviewing after a shopping experience reflected with great trustworthiness the satisfaction level with regard to service quality. Field research lasted three weeks and was performed on all weekdays, comprising morning, afternoon and evening periods.

Besides answering the 28 questions of the RSQ scale, clients were asked on their buying intention (or buying once more) in that particular shop and on the intention of recommending the shop to friends or relatives. Data analysis was achieved by modeling technique of structural equations.

Internal reliability indexes were satisfactory, with Cronbach's alpha coefficient between 0.81 and 0.92 for the five aspects and 0.74 for total scale. According to Dabholkar, Thorpe and Rentz (1996), high reliability reported by the scale suggested that service quality analysis was properly conducted at factor and sub-factor levels and at total scale level. Convergent and discriminating validities were verified in measuring model.

Although not a priority, the nomological validity of the scale suggested by Dabholkar, Thorpe and Rentz (1996) was verified, identifying the relationship between quality and intention aspects (buying/rebuying $-r^{2}=0.65$ ) and recommendation $\left(\mathrm{r}^{2}=0.70\right)$.

\subsection{Application of RSQ Scale}

Blose, Tankersley and Flynn (1999) employed the RSQ scale as a tool for harvesting data in a six-week research, featuring 497 clients from 13 different food shops in the biggest supermarket network from the southeastern region of the USA. When means attributed by clients for the five factors and their respective sub-factors of the scale were related to the 'productivity' data from each shop (profit on sales and client flux per hour of attendance), it became evident that shops with the best performance were those that had the highest service quality indexes, according to the clients' point of view.

So that the adequateness of current instruments to measure the quality perception of retail services in the distribution of technical products could be verified, Mehta, Han, Lalwani \& Mehta (1999) interviewed 300 clients of electronic products shops in different shopping centers of Singapore. A posted questionnaire was divided into two sections: the first section required respondents to evaluate service quality of the preferred electronic equipment supplier by using RSQ scale and the 22 questions of the quality perception of the SERVQUAL scale. The second section dealt with the respondents' social and economical profiles. Only 156 questionnaires were duly answered. Although in their conclusion Mehta et al. (1999) proposed a new scale to measure the quality perception in retailers that intensively worked in the commercialization of technical products, the authors mentioned that RSQ scale had the best performance when compared to the SERVQUAL scale. Further studies were suggested since the two scales validated in the United States have some non-relevant items for Singapore retailers. The small sample size was one limitations in the investigation.

Yang, Peterson and Cai (2003) mentioned another study developed in Japan by Mehta et al. in 2000. RSQ and SERVQUAL scales were applied to two distinct groups of retailers. The first retailer group demonstrated intense service with regard to business, whereas the second group was predominantly based on the commercialization of products. Mehta et al. (2000 apud Yang, Peterson \& Cai, 2003) concluded that SERVQUAL scale was more appropriate in the analysis of perceived quality of services of the first group, whereas RSQ scale was more efficient in the second group.

Kim and Jin (2002) conducted an exploratory study to determine the validity of the RSQ scale in measuring perceived quality of services in US and Korean retailers. Researchers applied questionnaires on two samples. The first sample comprised 214 university students from the eastern region of the USA and the second comprised 217 students from two universities in Seul, Korea. Samples were predominantly made up of female students $(89.7 \%$ in the USA and $82.5 \%$ in Korea). Most (respectively $55 \%$ and $78.1 \%$ ) had bought products in retail shops within a week from the date in which the questionnaire was filled. The statistical analysis of RSQ scale foregrounded the same quality factors in the two samples under analysis and suggested that consumers from the two different cultures failed to make any distinction between personal interaction and problem solution. Further, the factor internal policy 
was not complied with by students from the two countries.

So that the five quality factors investigated by Thorpe and Rentz (1996) could be correlated with the constructs Satisfaction and Reliability, Ramayah and Leen (2003) focused on clients of two great textile retailers in Malaysia. Two hundred and thirty questionnaires were applied, with a validation of 221. Ramayah and Leen (2003) concluded that generally the five quality factors identified in the study by Dabholkar, Thorpe and Rentz (1996) might affect the clients' satisfaction. They showed that satisfaction is rather linked to physical aspects than to personal interaction and internal policy. Trust is highly correlated with Reliability and Problem Solution. The authors suggested further studies since the sample was extremely small and 186 respondents were students and, consequently 181 (85.8\%) did not have any job. This last datum actually constituted a different trended aspect.

In spite of the fact that RSQ scale was successful in research work in South Africa and in Singapore and was validated in the perceived quality analysis of clients of the retail section of super- and hyper-markets and department stores Dabholkar, Thorpe and Overby (2005), Kaul (2005) verified the tool's validity when applied to consumers in Bangalore, India. The sample was defined by a quota system with selection criteria involving gender, income and age of respondents identified within a sampled client population of big local textile retailers. Data were collected by interviewers that obtained information at the respondents' home. Field survey lasted two months and 180 interviews were collected at the end of the period, but only 144 were valid. The interviewed demonstrated their service quality perception by a 7-point Likert scale for 26 out of 28 original questions of the RSQ scale. Questions 20 (Shop personnel are always amiable on the phone) and 28 (The shop has its own credit cards) were not applied since Hindi retail culture lacked these factors. Statistical analysis validated only 3 out of the five factors suggested by Dabholkar, Thorpe and Rentz (1996). Physical Aspects, Problem Solution and Internal Policies only were validated for the sample given. Kaul (2005) listed some limitations that impaired generalizations, namely, a small-sized sample, the sample's great homogeneity formed by inhabitants of the same city and people with similar profiles and, most significant for researchers, the lack of adaptation of the RSQ scale for Hindi retail conditions.

Meng, Summey, Herndon \& Kwong (2009) applied RSQ scale to a sample composed of 400 clients of an important supermarket network in Hong Kong, China, which holds approximately $70 \%$ of the local market. Researchers employed a modified scale with only 18 out of the original 28 items. Results showed four factors in perceived quality and explained $68.5 \%$ of the sample's variance. The authors revealed the great cultural difference between East and West as the main motive for the employment of only 18 items of the original RSQ. The decision strongly affected results. However, they showed that one of the scale's merits was its parsimoniousness.

\subsection{Application of the RSQ Scale in Brazil}

Lopes, Hernandez and Nohara (2009) compared the result of perceived quality measurement by RSQ and SERVQUAL in a sample of 351 clients of a building material network of shops. The authors did not show the theoretical constitution of the five factors when employing SERVQUAL and they demonstrated the superiority of RSQ when they performed the nomological validity test. Whereas SERVQUAL justified only $11 \%$ of variance of the sample's loyalty, RSQ explained 43\%. The researchers insisted on the need for further RSQ applications within the Brazilian scenario under two main headings: lack of studies on the tool in Brazil (theirs was the first in the country) and the quality of the results obtained by applying the scale proposed by Dabholkar, Thorpe and Rentz (1996).

The above review of the literature suggested Figure 1 which briefly explains, on a temporal basis, the main academic applications of the RSQ scale.

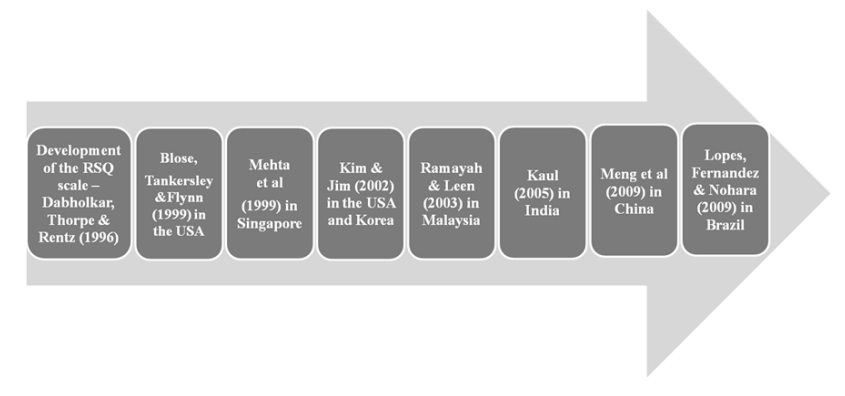

Figure 1. Main application of the RSQ scale. Source: bibliographical review

It should be underscored that in the application of several retail formats in several countries since its invention in 1996, the RSQ scale proved to be reliable and efficacious. In fact, its performance was higher than other more traditional tools.

\section{Method}

Scale developed by Dabholkar, Thorpe and Rentz (1996), modified to Brazilian conditions, has been used in current scale. Since Lopes, Hernandez and Nohara (2009) provided the reverse translation of the 28 items of the original scale and warranted successfully its face value, the scale of these researchers was currently employed.

As in the studies by Dabholkar, Thorpe \& Rentz (1996) and Lopes, Hernandez \& Nohara (2009), the measurement of the 28 items was performed by a 5-point Likert-type scale, with 1 meaning total disagreement and 5 total agreement.

\subsection{Sample}

Data collection was undertaken by three distinct samples made up of consumers of the retail network. Clients of a bank agency, a sports shop and a clothes shop were interviewed. The two retail shops belonged to the Brazilian commercial network whilst the bank agency is a section of a highly important multinational bank with branches 
throughout Brazil. The formats were chosen due to the interest of researchers in verifying the application of the RSQ scale in retailers with difference attendance profiles, with variations in pure service levels and commercialization of tangible products and in different involvement levels between consumers and retailers.

Selection of interviewed clients was performed at convenience and thus a non-probabilistic sample was obtained (Hair, Anderson, Tatham \& Black, 2009). Although data generalization are not allowed, non-probabilistic samples are frequently used in applied social science research (Cooper \& Schindler, 2003) mainly due to low cost (Cooper \& Schindler, 2003; Malhotra, 2006). Cooper \& Schindler (2003) underscored that the validity of such a sample was basically associated to the supposition that it adequately represented the population to be analyzed. Since researched clients were approached within the retailers' milieu, nothing indicated low sample validity. Similar to current application, the original investigations by Dabholkar, Thorpe \& Rentz (1996) and Lopes, Nohara \& Hernandez (2009) employed non-probabilistic samples at convenience. The first study comprised 227 clients from seven retail shops belonging to US retail networks and the second study involved 351 clients from eleven shops from a São Paulo retail network.

\subsection{Procedures}

Interviewed clients were met at shop exits and data were collected on the spot. All participants were over 18 years old and all had bought products immediately prior to the interview. The above procedure was undertaken to guarantee that all interviewed would give their opinions on the attributes of the retailer under analysis.

Client approach was performed by trained interviewers. After asking clients whether they had undertaken any commercial transaction (buying of sports material or clothes or banking operation, according to the case) the interviewer handled out the questionnaire so that clients could evaluate the 28 items on the RSQ scale with regard to the retailer in question.

Data were collected between October 2010 and January 2011 in São Paulo, Brazil.

\subsection{Plan for Data Analysis}

Analysis techniques comprised descriptive statistics through frequency analysis of the sample's demographic characteristics by statistic software SPSS 15.0. Modeling of structural equations were performed with SmartPLS 2.0M3 (Ringle, Wende \& Will, 2005).

Modeling of structural equations was chosen because it allowed the evaluation of causal relationships between the constructs and the subsequent evaluation of the path coefficients (Jöreskog \& Söbom, 1993). Actually it was also the technique employed in the original investigation by Dabholkar, Thorpe and Rentz (1996). Estimates with PLS-PM (Partial Least Square - Path Modeling) or Partial
Minimum Squares - Path Modeling, which analyzes data matrixes by co-relationship, was chosen because it did not prescind from normal data distribution and a great number of observations was not required, as in Lisrel models (Jöreskog \& Söbom, 1993; Chin, 1996).

Structural modeling followed method recommended by Chin (1996). It initially verified the indicators' convergent validity characterized by loads higher than 0.50 between the indicator and the construct, and the discriminating validity by comparing the square root of AVE (mean extracted variance) and the co-relation coefficient between the constructs.

\section{Observed Results}

The main aim of current section is to demonstrate results obtained after data analysis produced by the three surveys.

\subsection{Results of Study 1 - Bank Agency}

Sample of the first study comprised 262 respondents, with $149(56.9 \%)$ females and $113(43.1 \%)$ males. Most of the sample was formed by single people (135 respondents or $51.5 \%$ ), aged between 18 and 30 years (180 respondents or $69 \%$ ). Most respondents informed a monthly income of up to three thousand Brazilian reals (148 respondents or $56.5 \%)$.

Data modeling of study 1 showed the need to eliminate 5 indicators of the construct Personal Interactions (P16, P17, $\mathrm{P} 18, \mathrm{P} 19$ and P20) since they provided a low load for the construct $(<0.50)$.

In the second attempt, indicators showed acceptable adjustments with the constructs and a good convergent validity was obtained. Analysis of discriminating validity followed. Table 4 shows that the mean variance roots extracted from the constructs were higher than the co-relationship between each construct. The discriminating validity of the model was thus proved.

Table 4. Discriminating validity of Study 1 - Bank Agency.

\begin{tabular}{lccccc}
\hline & $\begin{array}{l}\text { Physical } \\
\text { aspects }\end{array}$ & Trust & $\begin{array}{l}\text { Personal } \\
\text { interactions policy }\end{array}$ & $\begin{array}{c}\text { Internal } \\
\text { Solution } \\
\text { of } \\
\text { problems }\end{array}$ \\
\hline Physical aspects & 0.6211 & & & & \\
Trust & 0.3699 & 0.6475 & & & \\
$\begin{array}{l}\text { Personal } \\
\text { interactions }\end{array}$ & 0.2110 & 0.4208 & 0.7023 & & \\
Internal policy & 0.1037 & 0.1499 & 0.2186 & 0.6805 & \\
Problem Solution & 0.0826 & 0.1913 & 0.2149 & 0.2288 & 0.6950 \\
\hline
\end{tabular}

Note: Cells on the diagonal and underscored are the construct's AVE roots.

Figure 2 demonstrates that the factorial loads of the indicators lie between 0.542 (P27->Internal policies) and 0.760 (P21->Problem Solution). Likewise, structural coefficients lie between 0.436 (Problem Solution ->RSQ) and 0.761 (Trust ->RSQ).

All structural coefficients were significant $(p<0.01)$ since they were calculated by bootstrap re-sampling test with 1000 
replications (Ringle, Wende and Will, 2005). Further, coefficients of determination were adequate and varied between 19\% (Internal Policies $\mathrm{r}^{2}=0.19$ ) and 57\% (Trust $\left.\mathrm{r}^{2}=0.579\right)$.

RSQ scale proved to be adequate to measure perceived quality in the segment of bank service.

The removal of 5 indicators from the original scale was not unexpected. Aggressive automation in bank services, especially the employment of automatic teller machines and extensive on-line banking operations, caused a decrease in quality perception of personal inter-relationship and jeopardized attendance in bank agencies. In fact, this is a highly problematic issue since the RSQ scale seems to be unprepared to measure web services.

The high coefficient of the construct Trust $\left(\mathrm{r}^{2}=0.579\right)$ is tied to former studies which show that the construct is one of the most relevant attributes in the evaluation of banking service (Hernandez and Mazzon, 2008).

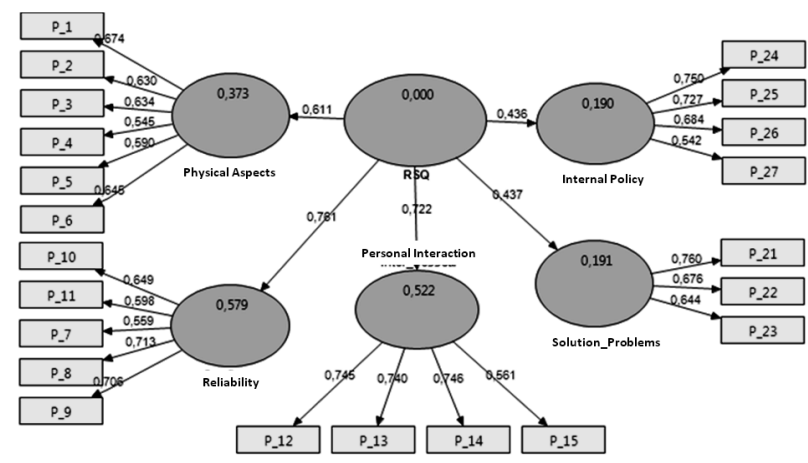

Figure 2. Final structural model of Study 1 (Bank agency).

\subsection{Results of Study 2 - Sports Shop}

The sample for the second study comprised 149 respondents, with $87(58.4 \%)$ males and $62(41.6 \%)$ females. Most people in the sample were single (90 respondents or $60.4 \%$ ), aged between 18 and 30 years old (78 respondents or $52.3 \%)$. Further, 113 respondents $(75.8 \%)$ had a university diploma.

During the first attempt for Study 2 data modeling, it was found necessary to eliminate 5 indicators, one of which was the construct Trust (P11), 1 item from the construct Personal Interaction (P14) and 3 items from the construct Internal Policies (P24, P27 and P28), with low factorial load $(<0.50)$.

In the second attempt the indicators showed adjustments which were acceptable to the constructs, with a resulting good convergent validity. The discriminating validity was then analyzed. Table 5 showed that the root of average variance extracted from the constructs was greater that the co-relation between each construct. The discriminating validity of the model was thus proved.

Figure 3 shows that the indicators' factorial loads lay between 0.504 (P18 ->Personal interactions) and 0.955 (P25 ->Internal Policies). Similarly, structural coefficients ranged between 0.495 (Internal policies -> RSQ) and 0.878 (Personal interactions ->RSQ). All structural coefficients were significant $(\mathrm{p}<0.01)$ and calculated by bootstrap re-sampling test with 1000 replications (Ringle, Wende and Will, 2005). Further, coefficients of determination were adequate and varied between 24\% (Internal policies $\left.\mathrm{r}^{2}=0.245\right)$ and $77 \%$ (Personal interactions $\mathrm{r}^{2}=0.771$ ).

Table 5.Discriminating validity of Study 2-Sports Shop.

\begin{tabular}{|c|c|c|c|c|c|}
\hline & $\begin{array}{l}\text { Physical } \\
\text { aspects }\end{array}$ & Trust & $\begin{array}{l}\text { Personal } \\
\text { interactions }\end{array}$ & $\begin{array}{l}\text { Internal } \\
\text { policy }\end{array}$ & $\begin{array}{l}\text { Solution } \\
\text { of } \\
\text { problems }\end{array}$ \\
\hline $\begin{array}{l}\text { Physical } \\
\text { aspects }\end{array}$ & 0.6768 & & & & \\
\hline Trust & 0.5170 & 0.6749 & & & \\
\hline $\begin{array}{l}\text { Personal } \\
\text { interactions }\end{array}$ & 0.4673 & 0.5985 & 0.6725 & & \\
\hline Internal policy & 0.2769 & 0.2852 & 0.2642 & 0.7692 & \\
\hline $\begin{array}{l}\text { Problem } \\
\text { Solution }\end{array}$ & 0.3604 & 0.3244 & 0.5627 & 0.5303 & 0.7921 \\
\hline
\end{tabular}

Note: Cells on the diagonal and underscored are the construct's AVE roots.

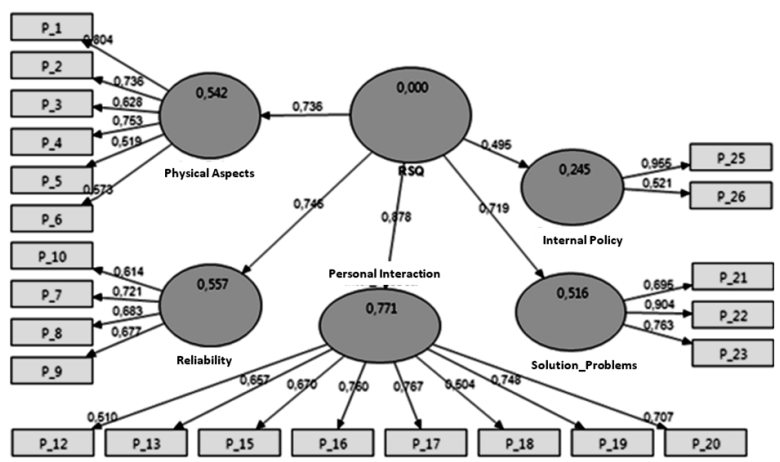

Figure 3. Final structural model of Study 2 (Sports shop).

Although low community level indicated the need to remove 5 indicators in current application, it seems that scale invented by Dabholkar, Thorpe and Rentz (1996) is adequate to measure perceived quality in the retailing format. The above is fore grounded on high coefficients of determination verified for all constructs (higher than 50\%), with the exception of Internal Policies jeopardized by the removal of 3 indicators.

The highest coefficient of determination was verified in the construct Personal Interactions $\left(r^{2}=0.771\right)$ which indicated the relevance of quality in attendance for the building of an image of high quality service in current retailing format. The construct Trust was relevant in the formation of the quality image $\left(r^{2}=0.557\right)$.

\subsection{Results of Study 3 - Clothes Shop}

The sample for the third study comprised 247 respondents, with $217(87.9 \%)$ females and 30 (12.1\%) males. Most of the sample involved married people (159 respondents or $64.4 \%$ ), aged between 18 and 35 years old (149 respondents or $60.3 \%$ ). Most respondents informed an income of up to three thousand Brazilian reals (142 respondents or $57.5 \%$ ).

During the first attempt for Study 3 data modeling, it was found necessary to eliminate 2 indicators, one indicator of the construct Trust (P11) and another from the construct 
Internal Policies (P28), both with low factorial load.

In the second attempt, indicators showed acceptable adjustments with constructs and resulted in good convergent validity. The discriminating validity was then analyzed. Table 6 shows that the root of average variance extracted from the constructs was greater that the co-relation between each construct. The discriminating validity of the model was thus proved.

Figure 4 shows the indicators' factorial loads ranging between 0.597 (P25->Internal policies) and 0.871 (P22->Solution of Problems). Likewise, the structural coefficients ranged between 0.721 (Internal policies->RSQ) and 0.947 (Personal Interactions RSQ). All structural coefficients were significant $(p<0.01)$ since they were estimated by bootstrap re-sampling tests with 1000 replications (Ringle, Wende and Will, 2005). Further, coefficients of determination were adequate and varied between 52\% (Internal Policies $\mathrm{r}^{2}=0.520$ ) and $89 \%$ (Personal interaction $\left.\mathrm{r}^{2}=0.897\right)$.

Table 6. Discriminating validity of Study 3 - Clothes Shop.

\begin{tabular}{|c|c|c|c|c|c|}
\hline & $\begin{array}{l}\text { Physical } \\
\text { aspects }\end{array}$ & Trust & $\begin{array}{l}\text { Personal } \\
\text { interactions }\end{array}$ & $\begin{array}{l}\text { Internal } \\
\text { policy }\end{array}$ & $\begin{array}{l}\text { Solution } \\
\text { of } \\
\text { problems }\end{array}$ \\
\hline $\begin{array}{l}\text { Physical } \\
\text { aspects }\end{array}$ & 0.9147 & & & & \\
\hline Trust & 0.7265 & 0.9129 & & & \\
\hline $\begin{array}{l}\text { Personal } \\
\text { interactions }\end{array}$ & 0.6355 & 0.8194 & 0.8652 & & \\
\hline Internal policy & 0.5253 & 0.6348 & 0.6147 & 0.7149 & \\
\hline $\begin{array}{l}\text { Problem } \\
\text { Solution }\end{array}$ & 0.5073 & 0.7375 & 0.8370 & 0.6366 & 0.9612 \\
\hline
\end{tabular}

Note: Cells on the diagonal and underscored are the construct's AVE roots.

RSQ scale was adequate to measure perceived quality in the retailing sector. The coefficients of determination in the application were very high and all structural paths were significant $(p<1 \%)$. Similar to Study 2 , the highest coefficients of determination occurred in the constructs Personal Interactions $\left(\mathrm{r}^{2}=0.897\right)$ and Trust $\left(\mathrm{r}^{2}=0.837\right)$, with a clear trend in results.

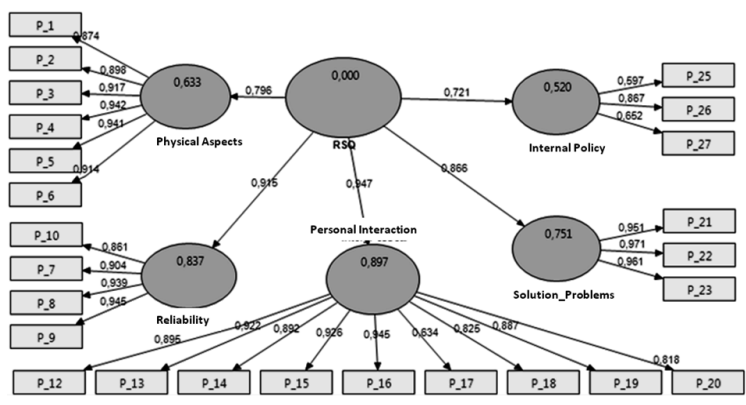

Figure 4. Final structural model of Study 3 (Clothes shop).

\subsection{General Discussion}

Table 7, comprising the coefficients of determination of each construct for each study, was composed to discuss fully and completely the results of the three surveys.
Table 7. Coefficients of determination in the three studies.

\begin{tabular}{lccc}
\hline \multicolumn{1}{c}{ RSQ factors } & Bank agency & Sports shop & Clothes shop \\
\hline$\left(\mathrm{r}^{2}\right)$ Physical aspects & 0.373 & 0.542 & 0.633 \\
$\left(\mathrm{r}^{2}\right)$ Trust & 0.579 & 0.557 & 0.837 \\
$\left(\mathrm{r}^{2}\right)$ Personal interactions & 0.522 & 0.771 & 0.897 \\
$\left(\mathrm{r}^{2}\right)$ Internal policies & 0.190 & 0.245 & 0.520 \\
$\left(\mathrm{r}^{2}\right)$ Solution of Problems & 0.191 & 0.516 & 0.751 \\
\hline
\end{tabular}

As Table 7 demonstrates, quality perception of services of retail consumers is mainly explained by Trust and Personal Interactions which occur precisely within the retailing milieu. They were the constructs which had the best co-relationship with perceived quality in the three formats under analysis.

Trust as a relevant factor in the banking milieu has always been acknowledged. It was also highly important for the other retaining formats. Recent studies on consumers' behavior in e-commerce already indicated the high concern that retailers have on Trust by clients and how such indicator may affect business (Brei and Rossi, 2005). Results of this research suggested that retailing concern should not be restricted to the electronic milieu. Consumers' Trust explained most of the perceived quality of services in the three retailing formats under analysis and, in a special way, in the fashion segment. There are signs that being positive and maintaining the availability of good products for clients, the core of retailing transactions, is still the best strategy to create an image of operational and commercial quality. There are also signs that the tangibility degree of the commercialized product does not affect the need for maintaining the clients' Trust.

Even if the three formats under analysis are underscored by the self-service system, by which clients go around freely and may not require the intervention of any personnel, the attendance aspect is still highly relevant to form the image of the retailing quality. This is also the case of the banking milieu where automation has been a feature for many years. Humanized attendance is still highly appreciated by clients. Results show that, in spite of the fact that self-service results in a broadening of commercial capacity in a retailing institution, it is mandatory that the segment's administrators give priority to the maintenance of personal attendance and invest in the selection and upgrading of specific personnel. Current result has already been expected since this factor is highly relevant in the evaluation of perceived quality in former analyses. As an exchange milieu, retailing requires personal contacts between clients and personnel.

It seems that clients do not distinguish the physical attributed of a banking agency from another since the variable does not have a strong co-relationship with perceived quality. The above may not be applied to the retailing formats in which tangible products may be acquired. A good physical aspect level of the banking agency may be a sine qua non condition for clients since it is believed that organizations dealing with banking operations are highly 
organized, profit-making and strong. Current study found that Physical Aspects is more relevant for the clothes shop than for the other format studied. Even if the construct is relevant for the Sports shop, it seems that the perceived quality of a clothes shop is highly affected by the evaluation of its physical aspects. Further, the sample's profile, predominantly feminine, highlights this specific valorization of the retailing attribute. Although the samples by Dabholkar, Thorpe and Rentz (1996) was predominantly feminine $(86,7 \%)$, the factor Tangible Aspects had the lowest influence in the formation of the services' perceived quality, although the authors failed to specify the trading section of the two shop networks.

Strangely enough, the coefficient of determination of the factor Solution of Problems was very different among the three formats, especially in the quality evaluation of the banking agency. The phenomenon may be explained by the low incidence of problems experienced by the respondents. A post hoc analysis identified low mean variance of the three items that measured the construct $(\mathrm{M}=4.18$; $\mathrm{dp}=0.16)$.

A greater influence on the perceived quality of services may exist when the retailer makes an effort to be correct from the start rather than when he tries to correct a mistake. The aggregated analysis of empirical studies corroborates the above when the indicators Trust and Solution of Problems are compared.

The factor Internal Policies had the lowest influence on the perceived quality of the analyzed retailers. If the above was expected from a banking agency, since certain variables of the factor allude to the payment form of products and to the adequate attendance timetable, standardized in the banking institution, as portrayed Thompson (2011) explaining the importance of politics and moral practices in consumption, it was expected that the factor were more relevant for the two formats. The coefficient of determination of this factor for the clothes shop was not low (0.52), albeit the lowest of the five factors. In the case of the Sports shop, only two variables of the factor were significant (adequate time schedule and proper parking space). Although the shop under analysis has its own credit card and accepts all other cards, it seems that these facts have not been perceived or valued by clients.

As a rule, RSQ scale showed a good adjustment for the three formats under analysis. In fact, few items were removed in the construction of the structural models. Another favorable point that should encourage further academic and administrative applications of the RSQ scale is the confirmation of the multi-dimensional constitution of perceived quality. In any case, all the constructs were valid and significant.

\section{Conclusions}

The final section highlights the contributions achieved by current study, identifies its limitations and proposes new academic studies on the theme.

Phenomena identified in current analysis may help marketing and retailing administrators. The identification of the influence of Trust in quality image shows that administrators should double their attention on the positivity of their business strategies since the consumer is rarely tolerant of mistakes, even if they are later set right.

The importance of attendance personnel reinforces the need for training and upgrading. Similar to upgrading technology in displaying products to enhance self-service, the organizations' human capital is of primary importance since personnel is much more valorized than the physical attributes of the retailer.

In the case of communication, payments should be underscored especially if they are differentiated from those of the competing firms. Firms that concede their own credit cards should enhance benefits attributed in such a financial product through acknowledgment programs or prize-giving. In the case of firms without this type of concession, it is recommended that they verify whether such service is perceived as a competitive differential with regard to the other competing firms.

The study's main administrative contribution was the undertaking of a comparative analysis of quality perception of services of three distinct retailing formats. Through the use of instruments scantily employed in Brazil, the influence of five theoretical factors in the formation of perceived quality was verified. Similar to former studies, the RSQ scale was low cost and easily applied since it was a direct evaluation of its 28 indicators. The identification of the strong influence of the factor Trust in the different formats should be indicated as a progress in market studies.

From the scientific point of view, perceived quality studies in services is still at a fledging state. It is expected that results of such applications trigger further initiatives to increase studies on the theme which would improve the perceptual differences of consumers in distinct organizational formats that underlie the retailing market.

The study's limit lies in the transversal cut in data collection. If, on the one hand, the technique has provided a photograph of the moment with regard to quality perception by consumers of the three formats under analysis, on the other hand, it is actually a limitation since the change of the same perception through time is not perceived. A longitudinal study is thus suggested, even with only one or two formats so that environmental and temporal factors would affect quality perception.

Another limiting factor was the lack of adaptation of certain items for a better description of the retailing format analyzed. Since there is practically no commercialization of tangible products In the case of the banking agency, several indicators were not validated. Item adaptation for the segment featuring low tangibility would be a relevant contribution.

Most academic studies on services' perceived quality deals with the identification or development of psychometric scales that make possible measurement with reliability and at low cost. It is believed that the RSQ scale developed by Dabholkar, Thorpe and Rentz (1996) is an interesting option 
for such ends.

Although several applications of the RSQ scale have been undertaken during the last fifteen years worldwide, it is still scantily employed in Brazil. Current analysis aimed at demonstrating its applicability within the Brazilian retailing context through three surveys.

When the scale's application is evaluated, it may be perceived that it is adequate for the measurement of services' perceived quality in Brazilian retail sector since the five quality factors underscored by Dabholkar, Thorpe and Rentz (1996) and the verification of facts could be identified with a greater or lesser relevance for each retail format when comparing results of its application to a banking agency, sports shop and clothes shop.

Current analysis infers that the research's aim was achieved. Even if the scale is modified to attend to specificities of each time of retailing, results show its strong and weak points. The main academic contributions of current study consist of the broadening of the debate on perceived quality in services and deepening understanding on a measuring tool which is still rarely employed.

The review of the literature on the theme showed current authors that there is great interest on the subject, especially within the retailing context. However, no established agreement exists since further studies on the theme should be done systematically. It is expected that current study would further the understanding of quality perception within the retailing sector.

\section{References}

[1] Beinstock CC, Mentzer, JT and Bird MM (1997) Measuring physical distribution service quality. Journal of the Academy of Marketing Science: 25(1): 31-44. doi: 10.1007/BF02894507

[2] Blose JE, Tankersley WB and Flynn (1999) Managing service quality using data envelopment analysis. Journal QMJ on line: 12(2).

[3] Brei VA and Rossi CAV (2005) Confiança, valor percebido e lealdade em trocas relacionais de serviço: um estudo com usuários de Internet Banking no Brasil. Revista de Administração Contemporânea: $\quad 9(2)$ : 145-168. http://dx.doi.org/10.1590/S1415-65552005000200008

[4] Carman JM (1990) Consumer perceptions of service quality: An assessment of the SERVQUAL dimensions. Journal of $\begin{array}{llll}\text { Retailing: } \quad 66 & (1): & 33-55 .\end{array}$ 10.1016/S0148-2963(99)00084-3

[5] Chin WW (1996) Partial least squares is to Lisrel as principal components analysis is to common factor analysis. Tecnology Studies: 2 (1): 315-319.

[6] Cooper DR and Schindler PS (2003) Métodos de pesquisa em administração Porto Alegre: Bookman.

[7] Cronin J and Taylor S (1992) Measuring Service Quality: a reexamination and extension. Journal of Marketing: 56(3): 55-68. doi: $10.2307 / 1252296$
[8] Dabholkar PA, Thorpe DI and Overby JW (2005) Linking process and outcome to service quality and customer satisfaction evaluations. International Journal of Service Industry Management: 16(1): 10-27. doi $10.1108 / 09564230510587131$

[9] Dabholkar, P.A., Thorpe, D.I., and Rentz, J.O. (1996). A measure of service quality for retail stores: scale development and validation. Journal of the Academy of Marketing Science, 24(1), 3-16.doi: 10.1177/009207039602400101

[10] Finn DW and Lamb CW (1991) An evaluation of the SERVQUAL scales in retail setting. Advances in Consumer Research: 18(2): 483-490.

[11] Guiry M, Hutchinson W and Weitz BA (1992) Consumer's Evaluation of Retail Store Service Quality and Its Influence on Store Choice. Working paper: University of Florida.

[12] Hair JF, Anderson RE, Tatham RL and Black WC (2009) Análise Multivariada de Dados. 6.ed. Porto Alegre: Bookman.

[13] Hernandez JMC and Mazzon JA (2008) Um estudo empírico dos determinantes da adoção de internet banking entre não usuários brasileiros. Revista de Administração Contemporânea: 12(special issue): 9-39.

[14] Hong S and Goo YJJ (2004) A causal model of customer loyalty in professional service firms: an empirical study. International Journal of Management: 21(4): 531-540.

[15] Jöreskog K and Söbom D (1993) Structural Equation Modeling with the SIMPLES Command Language. Lincolnwood: SSI.

[16] Kaul S (2005) Measuring retail service quality: examining applicability of international research perspectives in India. Indian Institute of Management: Ahmedabad-India, Research and Publications.

[17] Kim S and Jin B (2002) Validating the retail service quality scale for US and Korean customers of discount stores: an exploratory study. Journal of Services Marketing: 16(3): 223-237. doi: $10.1108 / 08876040210427218$

[18] Lopes EL, Hernandez, JMC and Nohara JJ (2009) Escalas concorrentes para a mensuração da qualidade percebida: uma comparação entre a Servqual e a RSQ. Revista de Administração de Empresas, São Paulo: 49(4): 401-416. doi 10.1590/S0034-75902009000400004.

[19] Malhotra NK (2006) Pesquisa de Marketing: uma orientação aplicada. 4. ed. Porto Alegre: Bookman.

[20] Mehta SC, Han S, Lalwani AK and Mehta SS (1999) Service quality of retailers distributing technical products: an extension. International Journal of Retail \& Distribuition Management: 28(2): 62-72.

[21] Meng J, Summey JH, Herndon NC and Kwong KK (2009) Some retail service quality expectations of Chinese shoppers. International Journal of Market Research: 51(6): 773-796.

[22] Parasuraman A, Zeithaml VA and Berry LL (1985) A conceptual model of Service Quality: Its implications for future research. Journal of Marketing: 28(2): 41-50. doi: $10.2307 / 1251430$ 
[23] Parasuraman A, Zeithaml VA and Berry LL (1988) SERVQUAL: A multiple item, scale for measuring consumer perceptions of service quality. Journal of Retailing: 64(2): $12-40$.

[24] Ramayah T and Leen JYA (2003) What drives relationship quality? A study of two retail clothing stores. 5th Asian Academy of Management Conference: "Challenges of Globalized Business: The Asian Perspective", Malaysia, 10th-13th September.

[25] Ringle CM, Wende S and Will A (2005) SmartPLS 2.0 M3 (beta). Germany: University of Hamburg, 2005. Disponível em: <http://www.smartpls.de>. Acesso em: 18 Nov 2011.

[26] Sharma S, Netemeyer RG and Mahajan V (1990) Search of excellence revisited: an empirical evaluation of Peters and
Waterman's attributes of excellence. In: William O. Bearden and A. Parasuraman (Eds). Enhancing knowledge development in marketing, Chicago: American Marketing Association, pp. 322-328.

[27] Sujan H, Weitz BA and Kumar N (1994) Learning Orientation, Working Smart, and Effective Selling. Journal of Marketing: 58(3): 39-52. doi: 10.2307/1252309

[28] Thompson C (2011) Understanding Consumption as Political and Moral Practice. Journal of Consumer Culture: 11(2): 139-144. doi: 10.1177/1469540511403892

[29] Yang Z, Peterson RT and Cai S (2003) Services quality dimensions of internet retailing: an exploratory analysis. Journal of Service Marketing: 17(7): 685-700. doi: $10.1108 / 08876040310501241$ 